\title{
Granitic Boulder Erosion Caused by Chaparral Wildfire: Implications for Cosmogenic Radionuclide Dating of Bedrock Surfaces
}

\author{
Katherine J. Kendrick, ${ }^{1, \star}$ Camille A. Partin, ${ }^{2}$ and Robert C. Graham ${ }^{3}$ \\ 1. USGS, Pasadena, California, USA, 2. Department of Geological Sciences, University of Saskatchewan, \\ Saskatoon, Saskatchewan, Canada; 3. Department of Environmental Sciences, \\ University of California, Riverside, California, USA
}

\begin{abstract}
A B S T RA C T
Rock surface erosion by wildfire is significant and widespread but has not been quantified in southern California or for chaparral ecosystems. Quantifying the surface erosion of bedrock outcrops and boulders is critical for determination of age using cosmogenic radionuclide techniques, as even modest surface erosion removes the accumulation of the cosmogenic radionuclides and causes significant underestimate of age. This study documents the effects on three large granitic boulders following the Esperanza Fire of 2006 in southern California. Spalled rock fragments were quantified by measuring the removed rock volume from each measured boulder. Between $7 \%$ and $55 \%$ of the total surface area of the boulders spalled in this single fire. The volume of spalled material, when normalized across the entire surface area, represents a mean surface lowering of $0.7-12.3 \mathrm{~mm}$. Spalled material was thicker on the flanks of the boulders, and the height of the fire effects significantly exceeded the height of the vegetation prior to the wildfire. Surface erosion of boulders and bedrock outcrops as a result of wildfire spalling results in fresh surfaces that appear unaffected by chemical weathering. Such surfaces may be preferentially selected by researchers for cosmogenic surface dating because of their fresh appearance, leading to an underestimate of age.
\end{abstract}

\section{Introduction}

Wildfire exerts significant geomorphic change on a landscape. One such change is exfoliation of boulders, commonly observed after wildfires. In this phenomenon, flakes of rock become detached from the boulder or outcrop. Rocks spall when thermal expansion exceeds the tensile strength of the rock. Granitic rocks subjected to rapid heating spall at temperatures of $300^{\circ}-375^{\circ} \mathrm{C}$ in laboratory simulations, but they are unaffected by rapid heating up to $200^{\circ} \mathrm{C}$ and by slow heating up to $800^{\circ} \mathrm{C}$ (Blackwelder 1927). Granitic rocks containing $20 \%$ or more quartz are particularly susceptible, as quartz, when heated from room temperature to $570^{\circ} \mathrm{C}$, experiences volume expansion of $3.76 \%$ (Freeman et al. 1963; Winkler 1973).

Fire-induced spalling has been recognized previously and reported qualitatively (Blackwelder 1927; Emery 1944; Bierman and Gillespie 1991). In a wildfire within the Great Basin Sagebrush Community,

Manuscript received June 24, 2015; accepted February 10, 2016; electronically published May 23, 2016.

* Author for correspondence; e-mail: kendrick@usgs.gov. approximately half of the surface area of some boulders had spalled, although only $5 \%$ of boulders showed spalling (Bierman and Gillespie 1991), while in a chaparral wildfire more than $50 \%$ of the boulder surfaces were estimated to have been removed by spalling (Emery 1944). Two studies have quantified erosional losses of rocks due to wildfires (Zimmerman et al. 1994; Dorn 2003). To this point, no research has quantified fire-induced rock spalling in the chaparral landscapes of southern California.

This setting is particularly relevant because of the wide extent of chaparral in southern California (Fried et al. 2004). In addition, numerous faults traverse this landscape (fig. 1). Cosmogenic radionuclide (CRN) dating of boulders and rock outcrops is often used to constrain the timing of fault movement and landscape development. The importance of spalling as a rock erosional process is particularly relevant to CRN dating. Previous studies have emphasized the significance that wildfire erosion would have on CRN dating of rock surfaces (e.g., Gillespie 1987; Bierman and Gillespie 1991). In spite of these prior studies, many CRN ages continue to be calculated

[The Journal of Geology, 2016, volume 124, p. 529-539] (c) 2016 by The University of Chicago. All rights reserved. 0022-1376/2016/12404-0007\$15.00. DOI: 10.1086/686273 


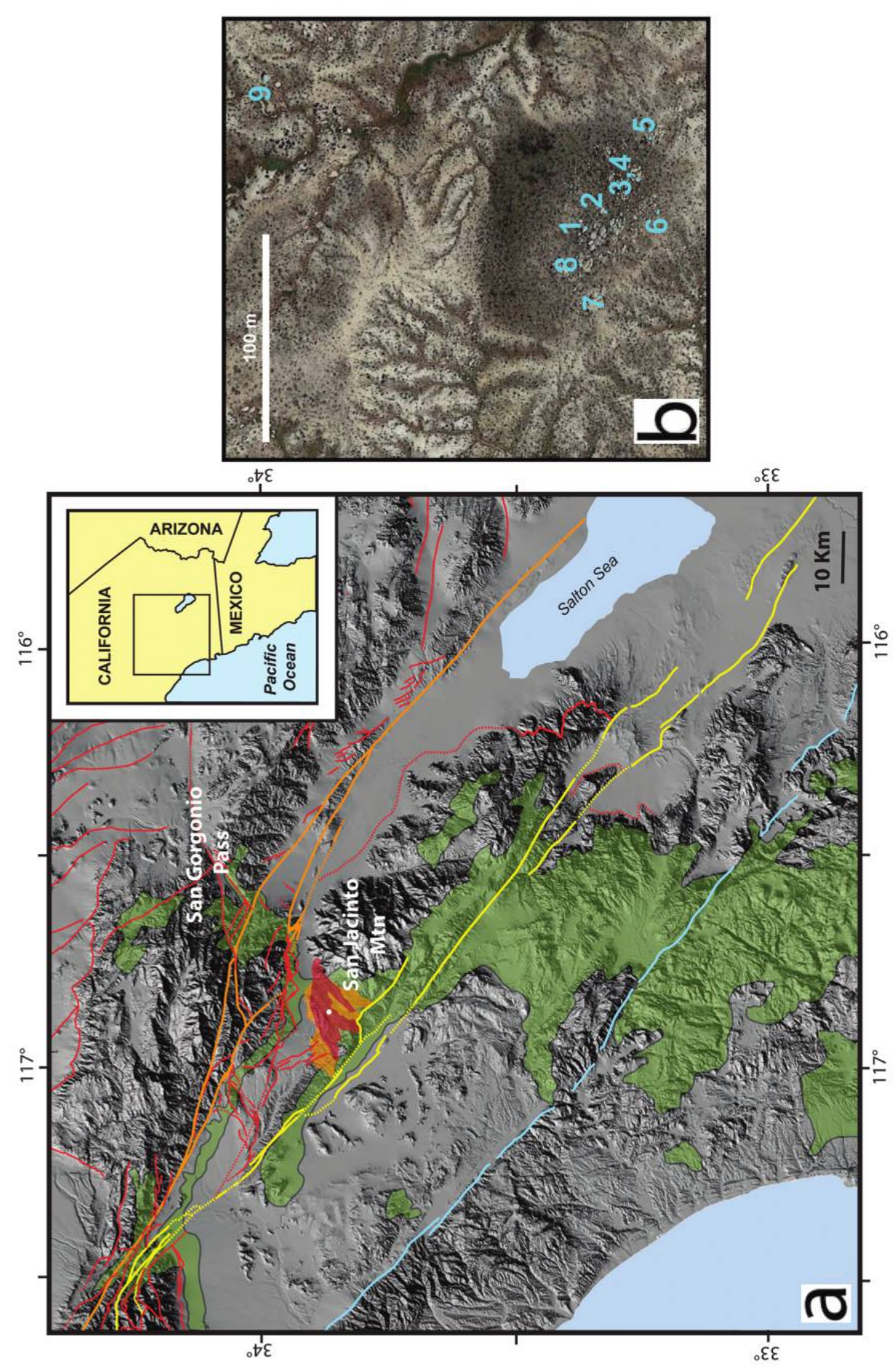

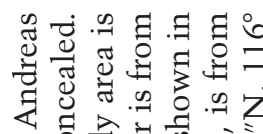

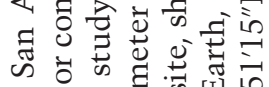

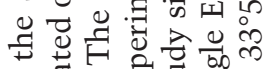

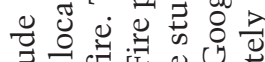

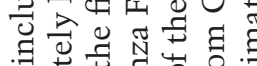

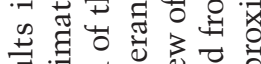

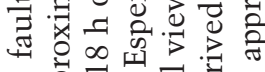

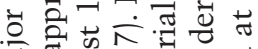
$\sum^{\pi}$ . 군

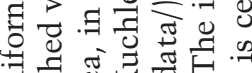

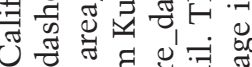
घ

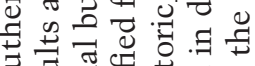

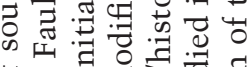
पे क.

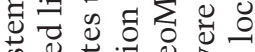
कि

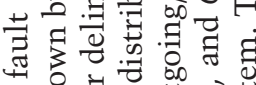
(

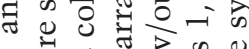

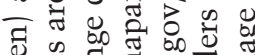

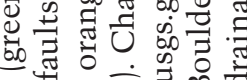

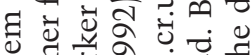

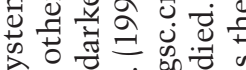
के

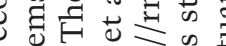
जั

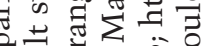
ब्षे ช

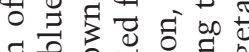

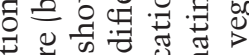

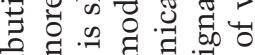
表

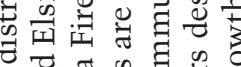

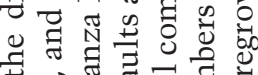
$\infty)^{3}$

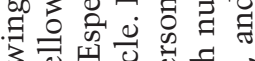

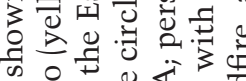

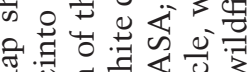

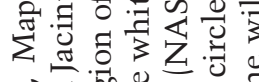
०

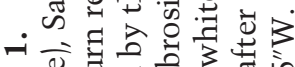

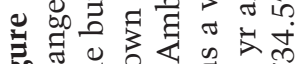

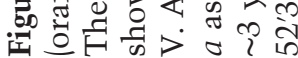


assuming negligible or no erosion of the rock surface. Even moderate rates of surface erosion $(10 \mathrm{~mm} /$ k.yr.) limit the range of effective age dating for this technique. Erroneous age calculations can result when these surface erosion rates are unknown. This study evaluates spalling in a chaparral community in southern California. Rock spalling data need to be considered if CRN dating techniques are to be meaningfully employed to estimate surface exposure ages of boulders.

\section{Methods}

Study Area. Our study area is on the northwestern side of the San Jacinto Mountains, at an elevation of $1165 \mathrm{~m}$ (fig. 1). The bedrock is comprised of mafic tonolite to granodiorite (Hill 1988). Soils and weathered bedrock in the area have been studied extensively (e.g., Graham et al. 1997).

The sample site is a stable upland within a weathering granitic terrain. Boulder occurrences represent the resistant portion of the landscape, located on hilltop positions. The rocks discussed here were primarily located on one such hilltop, roughly 125 by $85 \mathrm{~m}$ in aerial extent. The site was selected because it is representative of the larger region and is accessible. The orientation of the largest boulders aligns with primary jointing and indicates that they are weathering in place as exhumed corestones rather than having experienced transport. Many-if not most - of the rocks observed in this study area are not detached from the underlying bedrock. In landscape positions between these resistant bedrock outcrops and associated boulders, weathered bedrock (saprock) extends to depths as great as $3 \mathrm{~m}$ (Graham et al. 1997). For ease of discussion, we will refer to these partially exhumed corestones as boulders.

The vegetation at the site is a chaparral community, consisting of chamise, Eastwood manzanita, and cupleaf ceanothus (Graham et al. 1997). The vegetation was mature in 2006 at the time of the wildfire, reaching heights of $1.5-2 \mathrm{~m}$, and is very dense (fig. 2). Repeat aerial photography, beginning in 1938, shows that the study site had not burned since about 1920 (R. Minnich, personal communication, 2013).

The Esperanza Fire occurred in October 2006 during a period of high winds associated with the Santa Ana wind regime in southern California. Four years of drought (1999-2002) were followed by $3 \mathrm{yr}$ of normal precipitation (2003-2005) in the area prior to the fire. The fire was initiated at its eastern end (fig. 1) and burned until full containment $5 \mathrm{~d}$ later. The fire was extremely fast moving, burning $\sim 97 \mathrm{~km}^{2}$ in the first $18 \mathrm{~h}$. The length of the fire at a duration of $\sim 10 \mathrm{~h}$ was $16 \mathrm{~km}$; a computer simulation model of the fire with rates of spread ranging from 0.2 to $1.6 \mathrm{~m} / \mathrm{s}$ somewhat underestimated the actual fire dimensions (Coen and Riggan 2014). Thermal imaging was collected during the fire using airborne remote sensing (Riggan et al. 2010; Coen and Riggan 2014). This imaging showed that the highest fuel loads, associated with vegetation greater than $50 \mathrm{yr}$ old, corresponded with the highest temperatures. At its containment, the fire had burned more than $163 \mathrm{~km}^{2}$ (Esperanza Investigation Team 2007).

Within our study area, the Esperanza Fire falls within the definition of a high-severity chaparral fire, resulting in an extensive white ash layer and having a previously dense stand of chaparral burned to stubs (DeBano et al. 1998, p. 89). A similarly burned chaparral landscape reached $700^{\circ} \mathrm{C}$ at the soil surface and $250^{\circ} \mathrm{C}$ at a depth of $2.5 \mathrm{~cm}$ in the soil (DeBano et al. 1979, 1998). Other measurements of chaparral wildfires record temperatures up to $1100^{\circ} \mathrm{C}$ (Mooney and Parsons 1973).

Measurement Approach. To understand the effect of the Esperanza Fire on granitic boulders, we quantified the erosion caused by spalling. We directly measured the volume of rock material removed on the surface of the boulders rather than on the ground. By this approach, we could account for even the thinnest spalls. In our study area, only the thicker spalled fragments were still intact on the ground surrounding the boulder. By the time our measurements were made, $11 \mathrm{mo}$ after the fire, thinly spalled material could not be readily distinguished from older grus surrounding the boulder, so the approach used by Zimmerman et al. (1994) - measuring spalled rock flakes on the ground-would have significantly underestimated the erosional effect of the wildfire. By measuring the spalled area and volume (missing surface material) on the rock itself, we can account for a more complete erosional volume. We also documented and measured rock spalls that were still attached, although quite fragile. Similarly, Emery (1944), in a postfire investigation, noted the presence of detached spalls that had not yet fallen clear of the rock mass.

We made reconnaissance observations on nine boulders; eight ranged in height between 0.5 and $2 \mathrm{~m}$, and one was $4.5 \mathrm{~m}$ high. From this initial set of boulders, we selected three for more detailed study. These three boulders were chosen because we determined that they were representative of the degree of fire-generated surface erosion for this site. Additionally, because these boulders were located on low-angle slopes, the potential effect of slope gradient on wildfire intensity was minimized. On 

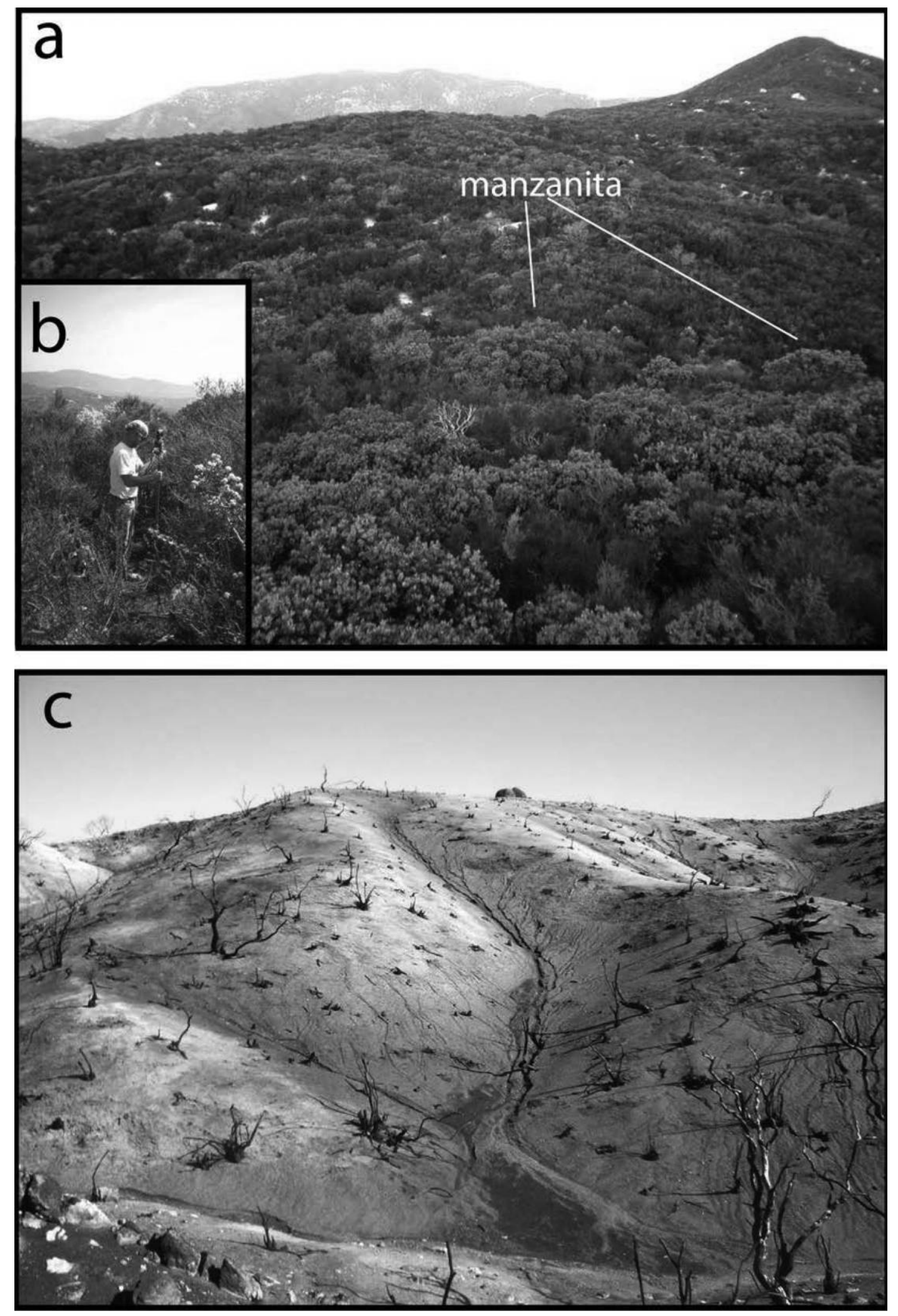

Figure 2. Photos of landscape and vegetation before and after the Esperanza Fire, showing density and height of vegetation. $a$, Vegetation at the study site prior to the wildfire, in 1993. View shows southwest-facing slope. Note the abundance of manzanita shrubs. $b$, Chaparral vegetation was $1.5-2 \mathrm{~m}$ high prior to the wildfire, also in 1993. $c$, Landscape 3 mo after the wildfire, in January 2007, also showing a southwest-facing slope. Photos by R. Graham. A color version of this figure is available online. 
this subset we measured the total volume of missing rock that was removed from the boulders after the passage of the burn front. The areas of removed rock were obvious because of the stark contrast between the fresh granitic rock and the unspalled charred surface (fig. 3). In addition to measurement of the rock fragments that were missing from the boulder surface, we measured platy fragments that we determined to be extremely fragile and likely to fall within a few seasons. These fragments had separated from the rock face but were still partially attached. Width, length, and depth measurements were collected. The depth of each missing fragment was measured along the edge of the spall and at multiple locations if it was uneven. Because the spall is likely thicker in the middle, where a depth could not be measured, the resulting volumes are likely minimum values only. Each spalled area was simplified to either a rectangular or circular shape, as appropriate, to calculate area. We estimate a $20 \%$ uncertainty in the measurement of area. This accounts for simplifying irregular shapes to a rectangle or a circle. This measure of area was combined with the average depth of that spall to calculate spalled volume. Photogrammetry was used to calculate the total boulder surface area. Multiple targets were affixed to the boulders, and then numerous photos were taken from all angles. These were used to create a model of the boulder, using PhotoModeler software. Although a detailed survey was not conducted, a review of photography from our field investigations suggests that more than $90 \%$ of all boulders experienced spalling in this wildfire.

\section{Results}

Spalling ranged from $7 \%$ to $55 \%$ of the exposed surface area of the three boulders studied in detail (table 1). This included the rock fragments that we anticipated would be completely separated within
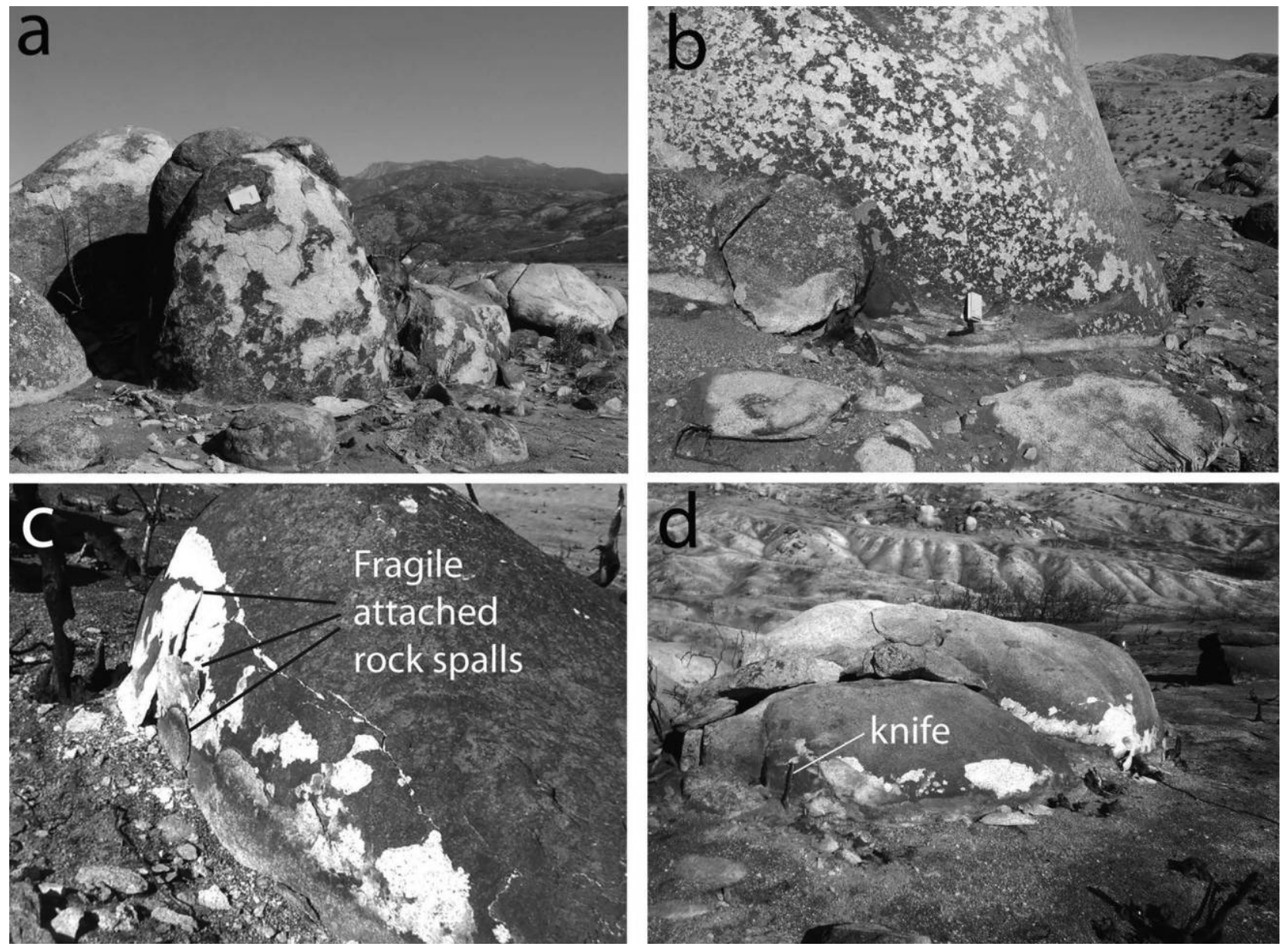

Figure 3. Photos of examples of postwildfire spalled boulders. Notebook is $19 \mathrm{~cm}$ tall. Boulder 1 is shown in $b$. A color version of this figure is available online. 


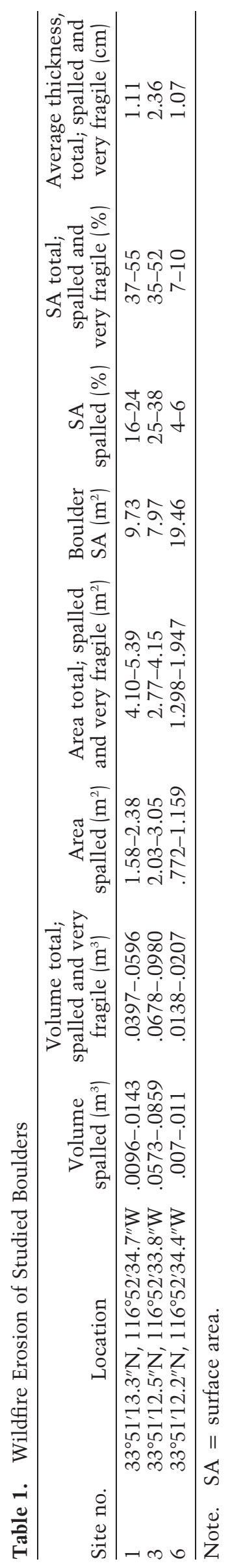

This content downloaded from 131.215.070.231 on August 04, 2016 07:50:14 AM 
a short time. We observed that the thickness of spalling was greatest on the flanks of the boulders, although this was not quantified. The uppermost portion of each rock was dominated by thin spalls that were $\sim 1 \mathrm{~mm}$ deep. The height of the charred surface extended to the top of all observed boulders with the exception of the largest one documented, where char height was $404 \mathrm{~cm}$ on a $438-\mathrm{cm}$-high boulder.

\section{Discussion}

Rate of Rock Erosion by Fire Spalling. Our qualitative observations suggest that the thickness of spalling varies with position on the rock, with the thickest spalls occurring on the lower flanks of the boulders. This is consistent with the differential stress conditions created by longer burning times where vegetation fuel loads are highest. The limbs of the shrubs generally grow up along the boulder flanks. These limbs generate more heat for a longer time interval than the smaller branches, which are in contact with the upper sides and sometimes the tops of the boulders.

We use the amount of surface erosion of the measured boulders in this single wildfire to estimate the interval of time at which the entire boulder surface may refresh by cumulative spalling. On the boulders studied in detail, the amount of surface erosion varied between $7 \%$ and $55 \%$ of the total surface area. This suggests that, on average, the entire surface of these rocks would be removed in the time represented by $2-14$ fires. Chaparral vegetation attains a closed canopy within 5-20 yr after burning and full height maturity within $40 \mathrm{yr}$ (Minnich and Chou 1997). Fire suppression in southern California has been practiced since 1900 (Minnich 1983). Estimates of presuppression fire intervals in chaparral range from 10 to $40 \mathrm{yr}$, while a regional fire-recurrence interval of 58-77 yr has been shown for the period since 1920 (Minnich and Chou 1997). We utilize an average return interval of $50 \mathrm{yr}$ (Chou et al. 1993) to suggest that the entire rock surface might be refreshed in 100-700 yr (e.g., 2-14 wildfires with an average return time of $50 \mathrm{yr})$. It must be noted, though, that because the distribution of spalling is not uniform in our observations of this wildfire, as discussed above, the surface of the boulder may not be uniformly refreshed over multiple wildfires.

The average thickness of the removed rock when distributed to the entire exposed area of the rock represents a mean surface lowering of $0.7-12.3 \mathrm{~mm}$ for this wildfire. As discussed, because of the measurement of thickness on the edge of the removed fragment, this value is considered a minimum. In comparison, Zimmerman et al. (1994) report an average surface erosion of $0.39 \mathrm{~mm}$ of the entire rock surface area in wildfire within a sagebrush ecosystem. Dorn (2003) reports greater than $42 \mathrm{~mm}$ of erosion for the diorite boulders in his study, located in the temperate evergreen needleleaf woodland (Kuchler 1964) in central Arizona, although the methodology used in calculating both the total surface area of each rock and the volume of eroded material is not clearly explained. The wide range of values for surface erosion calculated for the chaparral in southern California would likely be better constrained with further postfire measurements following future chaparral wildfires. If these rock-surface-lowering values from the Esperanza Fire are assumed to represent a typical fire effect and are multiplied by 20 fires per $1000 \mathrm{yr}$ (fire recurrence interval of $50 \mathrm{yr}$ ), then the rock erosion rate would range from 14 to $246 \mathrm{~mm} / \mathrm{k}$.yr. The high end of this range exceeds reported erosion rates based on ${ }^{10} \mathrm{Be}$ concentration in bedrock surfaces (e.g., Portenga et al. 2011) and does not seem to be a reasonable sustainable rate for this landscape. Our next consideration is whether the Esperanza Fire might be considered a typical chaparral wildfire.

Relation to Fire History. To evaluate the likelihood of this amount of erosion over longer terms, we need to consider the possible departure of the Esperanza Fire from an average chaparral wildfire. The rock-erosion effects of the Esperanza Fire may not represent those of all past wildfires in chaparral, but they likely reflect the erosion associated with a proportion of the prehistoric events. When ignition occurs in the absence of drought conditions and with high humidity and strong winds, wildfire can move rapidly through the chaparral, burning the brush canopy without delivering high temperatures to the ground surface. This effect occurs because the moist fuels in high-humidity conditions absorb thermal energy in latent heat exchange. In this situation, the severity of the chaparral wildfire would be considered low or moderate, and the temperatures that would be experienced by the lower boulders would be significantly less. Temperatures in low- and moderate-severity wildfires in chaparral have been measured at $225^{\circ}$ and $430^{\circ} \mathrm{C}$, respectively (DeBano et al. 1998). Granitic rocks exposed to lowseverity wildfires would be expected to experience a decrease in their modulus of elasticity (Goudie et al. 1992; Allison and Goudie 1994; Allison and Bristow 1999|, likely as a result of microfracturing, but may not exhibit extensive spalling (Blackwelder 1927).

Prior to the current public policy of fire suppression, wildfires in chaparral occurred during a variety of wind and humidity conditions, resulting in 


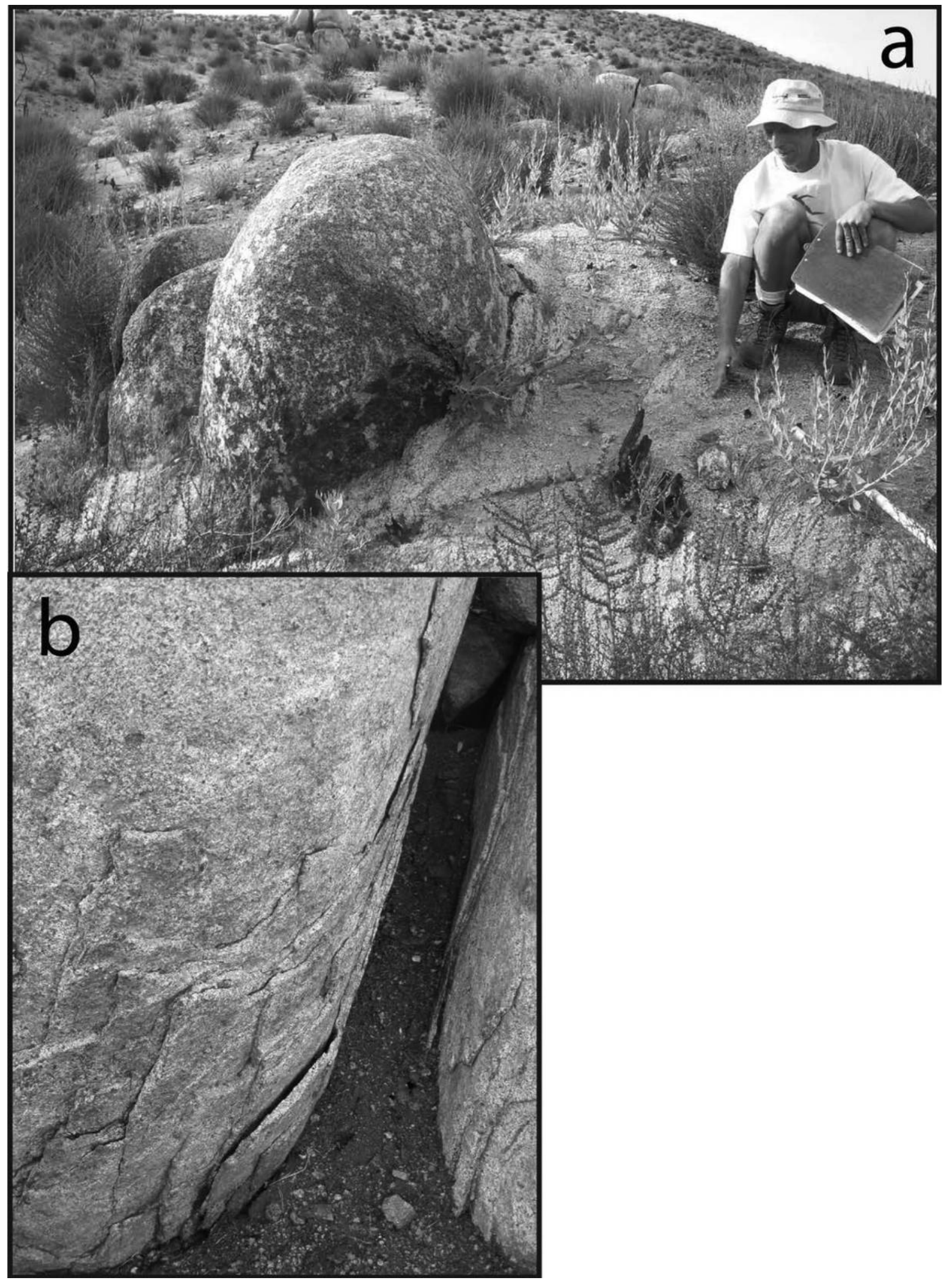

Figure 4. $a$, Bedrock flange surrounding boulder. Numerous spall remnants are present, to distance indicated by hand. $b$, Photo showing layered morphology. Layers of exfoliated, spalled surfaces are preserved on the sides of these adjacent boulders near their base. The preservation of these spalled but still attached layers may be due to the protected position between these boulders. A color version of this figure is available online. 
many fires that were slow moving (Minnich 1987). These fires would last for weeks and months, were small in area compared with recent extreme wildfires, and resulted in a patchwork of chaparral stands of differing ages (Minnich 1987; Goforth and Minnich 2007). The slow-moving wildfires are characterized by braided, reticulate configurations with numerous islands of unburned cover (Minnich and Chou 1997). Fires of this regime-documented in Baja California, where fire suppression is minimalare observed to have overall lower intensities (Minnich and Chou 1997).

Following the implementation of fire-suppression policy, slow-moving wildfires are extinguished and only very fast-moving wildfires escape control. This favors wildfires that occur during Santa Ana wind conditions, with moderate to high wind speeds and extremely low humidity. These dry, hot winds that originate in the Mojave Desert begin in the fall months, at the end of the dry period in the Mediterranean climatic zone. This corresponds to the time of lowest moisture in the chaparral. In addition, certain regions in southern California are favored for large, very intense wildfires as a function of local topography. The study area is one such region. It is positioned to receive the Santa Ana winds that flow through the San Gorgonio Pass and are diverted to the north around Mount San Jacinto (Moritz et al. 2010).

While precise interpretation of fire history is impossible, it is evident that spalling has been an ongoing process in the study area. There are examples of spalled but still-attached rock fragments that appear as a layered morphology on some boulders (fig. $4 b$ ). In many cases, a sequence of these spalled layers can be observed extending away from the base of the boulder as a broad flange (fig. $4 a$ ). Each of these layers is between $\sim 0.5$ to $2 \mathrm{~cm}$ thick, and they are progressively weathered and decrease in definition as a function of distance from the boulder.

Implications for Cosmogenic Dating. The effect of wildfire on erosion of bedrock surfaces has been documented by previous researchers (e.g., Blackwelder 1927; Emery 1944; Gillespie 1987; Bierman and Gillespie 1991; Zimmerman et al. 1994; Dorn 2003), and Gillespie (1987) and Bierman and Gillespie (1991) emphasized the significance that this wildfire erosion would have on CRN dating. In spite of this research, much of the CRN dating continues to assume zero to very low rates of bedrock erosion.

Matmon et al. (2005) utilized CRN dating to constrain the ages of fans offset along the San Andreas fault. They found a rock erosion rate that ranged between 17 and $160 \mathrm{~mm} / \mathrm{k}$.yr., calculated by measuring both ${ }^{10} \mathrm{Be}$ and ${ }^{26} \mathrm{Al}$ on bedrock outcrops within their study area. These researchers point out that the saturation of CRN concentration occurs when the production is balanced by decay and erosion. For an erosion rate of $20 \mathrm{~mm} / \mathrm{k}$.yr., saturation occurs at $\sim 50 \mathrm{ka}$ (Matmon et al. 2005).

The range of rock erosion rates estimated in the Esperanza Fire (14-246 mm/k.yr.) is similar to the range of erosion rates reported by Matmon et al. (2005). Erosion by fire is only one of a number of erosional processes operating in this setting, but it is one that strongly impacts bedrock outcrops and boulders. If even one out of 10 fire events was as severe as the Esperanza Fire, the effects of rock spalling would significantly restrict the time period over which ${ }^{10} \mathrm{Be}$ is a useful dating technique (fig. 5). Figure 5 demonstrates that erosion of rock surfaces significantly affects our ability to date these surfaces. At rock surface erosion rates of $30 \mathrm{~mm} / \mathrm{k}$.yr., we are unable to determine the age of the boulder accurately by measuring a single nuclide because of the contrasting processes of nuclide accumulation and removal.

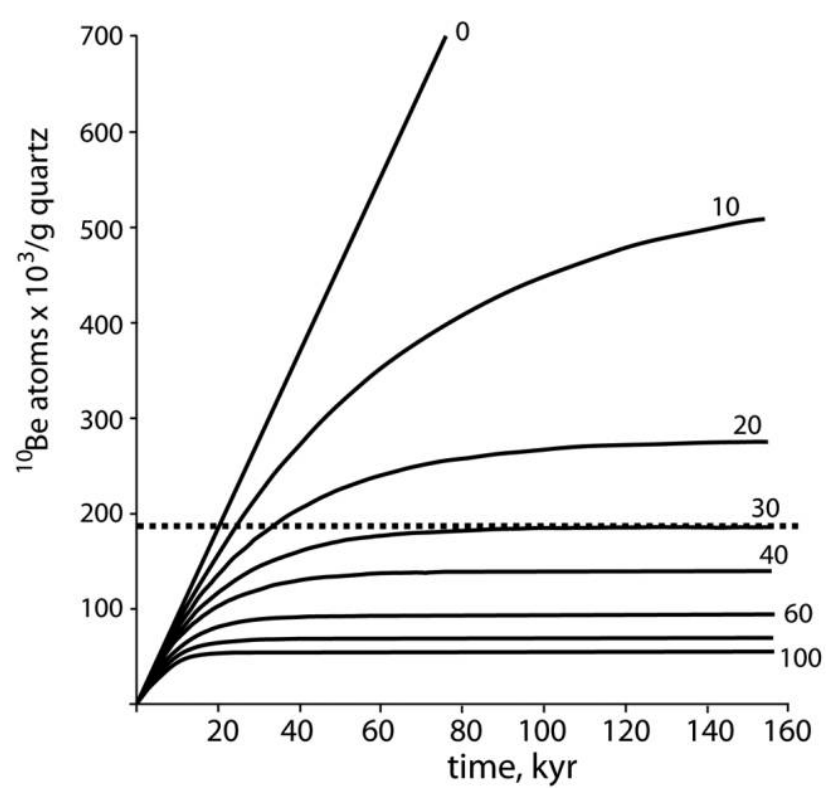

Figure 5. Saturation curves for ${ }^{10} \mathrm{Be}$ nuclide concentration in rock outcrops and boulders at the study site, based on calculations from the Chronus-Earth online calculator (Balco et al. 2008 and equations therein). Erosion rates $(\mathrm{mm} / \mathrm{k} . y r$.$) are shown by each curve. The horizontal dashed$ line provides an example of the effect of surface erosion on age determination. The assumption of no erosion would suggest an age of $20 \mathrm{ka}$. Erosion rates of 10 and $20 \mathrm{~mm} / \mathrm{k} . \mathrm{yr}$. lead to age determinations of 25 and $35 \mathrm{ka}$, respectively. At $30 \mathrm{~mm} / \mathrm{k}$.yr., this ${ }^{10} \mathrm{Be}$ concentration does not yield a unique age, due to the balance between accumulation of signal and removal by surface erosion. 
Sampling of boulders or bedrock outcrops in a chaparral community for CRN dating needs to be done with consideration of the effects of wildfire on the rock surfaces. The height of the effects of the wildfire significantly exceeds the height of the prefire vegetation. All but one of the boulders measured had been overtopped by the char and spalling level. A char line at $404 \mathrm{~cm}$ on the remaining boulder suggests that the height of the flame line was twice that of the vegetation. This is confirmed by measurements made immediately after the wildfire, where it was independently estimated that flame height was approximately 15 feet $(4.6 \mathrm{~m})$ at a location to the northeast of our study site (Esperanza Investigation Team 2007, p. 51). Thus, no part of a 4-m-high boulder is necessarily protected from the enhanced erosion caused by fire spalling. Wildfire spalling exposes fresh rock surfaces; because the spalling occurs as exfoliation, the curvature of the boulders and outcrops is maintained and possibly enhanced. These characteristics can falsely lead researchers to conclude that these surfaces are especially suited for CRN dating.

Consideration also needs to be given to the fact that Pleistocene-era vegetation communities were different from Holocene and Recent vegetation, a function of different climatic conditions (Minnich 2007). CRN dates calculated for surfaces spanning these intervals need to consider the entire history of vegetation type and the associated effects on fire behavior and rock surface erosion.

\section{Conclusions}

Chaparral wildfires represent a significant erosional process for bedrock and boulders. In the Esperanza Fire, between $7 \%$ and $55 \%$ of the total exposed surface area was spalled to a depth of 11-24 $\mathrm{mm}$ on the boulders investigated. When normalized across the entire surface area of the boulder, the depth of erosion ranged from 0.9 to $10 \mathrm{~mm}$. The height of the fire effects, including charred rock surfaces and spalling, significantly exceeded the height of the prefire vegetation at this site. Although the Esperanza Fire may not be a typical event, we propose that it is not unprecedented for the study area, given its location downwind from the San Gorgonio Pass. This amount of erosion leads to an underestimation of the age calculated by CRN dating by direct removal of rock surfaces. Although additional postwildfire measurements will be needed to develop a more robust data set, these results suggest that sampling for CRN dating needs to consider and account for the effects of wildfire boulder erosion.

\section{A C K N O W LED GMENTS}

This study benefited from early reviews by D. Ponti and K. Knudsen (USGS) and B. Goforth (California State University, San Bernardino). Thoughtful reviews were also provided by A. Gillespie (University of Washington) and G. Girty (San Diego State University).

\section{REFERENCES CITED}

Allison, R. J., and Bristow, G. E. 1999. The effects of fire on rock weathering: some further considerations of laboratory experimental simulation. Earth Surf. Process. Landf. 24:707-713.

Allison, R. J., and Goudie, A. S. 1994. The effects of fire on rock weathering: an experimental study. In Robinson, D. A. and Williams, R. B. G., eds. Rock weathering and landform evolution. New York, Wiley.

Balco, G.; Stone, J. O.; Lifton, N. A.; and Dunai, T. J. 2008. A complete and easily accessible means of calculating surface exposure ages or erosion rates from ${ }^{10} \mathrm{Be}$ and ${ }^{26} \mathrm{Al}$ measurements. Quat. Geochronol. 3: 174-195.

Bierman, P., and Gillespie, A. 1991. Range fires: a significant factor in exposure-age determination and geomorphic surface evolution. Geology 19:641-644.

Blackwelder, E. 1927. Fire as an agent in rock weathering. I. Geol. 35:134-140.

Chou, Y. H.; Minnich, R. A.; and Chase, R. A. 1993. Mapping probability of fire occurrence in San Jacinto
Mountains, California, USA. Environ. Manag. 17:129_ 140.

Coen, J. L., and Riggan, P. J. 2014. Simulation and thermal imaging of the 2006 Esperanza wildfire in southern California: application of a coupled weather-wildfire model. Int. I. Wildland Fire 23:755-770.

DeBano, L. F.; Neary, D. G.; and Ffolliott, P. F. 1998. Fire's effects on ecosystems. New York, Wiley.

DeBano, L. F.; Rice, R. M.; and Conrad, C. E. 1979. Fire's effect on physical and chemical properties of chaparral soils. In Mooney, H. A., and Conrad, C. E., tech. coord. Proceedings of the Symposium on the Environmental Consequences of Fire and Fuel Management in Mediterranean Ecosystems. USDA Forest Service, General Technical Report WO-3, p. 65-74.

Dorn, R. I. 2003. Boulder weathering and erosion associated with a wildfire, Sierra Ancha Mountains, Arizona. Geomorphology 55:155-171.

Emery, K. 1944. Brush fires and rock exfoliation. Am. I. Sci. 242:506-508. 
Esperanza Investigation Team. 2007. Esperanza Fire accident investigation factual report, Riverside County, CA. Accessed January 23, 2015. http://www.fire.ca.gov /fire_protection/downloads/esperanza_00_complete _final_draft_05_01_2007.pdf.

Freeman, D. C.; Sawdye, J. A.; and Mumpton, F. A. 1963. The mechanism of thermal spalling in rocks. Colo. Sch. Mines Q. 58:225-252.

Fried, J. S.; Bosinger, C. L.; and Beardsley, D. 2004. Chaparral in southern and central coastal California in the mid-1990's: area, ownership, condition, and change. USFS Resour. Bull. PNW-RB-240.

Gillespie, A. R. 1987. ${ }^{40} \mathrm{Ar}-{ }^{39} \mathrm{Ar}$ "exposure" ages of geomorphic surfaces: the effect of range fires. Eos Trans. Am. Geophys. Union 68:1286-1287.

Goforth, B. R., and Minnich, R. A. 2007. Evidence, exaggeration, and error in historical accounts of chaparral wildfires in California. Ecol. Appl. 17:779-790.

Goudie, A. S.; Allison, R. J.; and McLaren, S. J. 1992. The relations between modulus of elasticity and temperature in the context of the experimental simulation of rock weathering by fire. Earth Surf. Process. Landf. 17:605-615.

Graham, R. C.; Schoenberger, P. J.; Anderson, M. A.; Sternberg, P. D.; and Tice, K. R. 1997. Morphology, porosity, and hydraulic conductivity of weathered granitic bedrock and overlying soils. Soil Sci. Soc. Am. I. 61:516-522.

Hill, R. I. 1988. San Jacinto intrusive complex 1: geology and mineral chemistry, and a model for intermittent recharge of tonolitic magma chambers. I. Geophys. Res. 93:10,325-10,348.

Kuchler, A. W. 1964. Potential natural vegetation of the conterminous United States. Am. Geogr. Soc. Spec. Pub. No. 36

. 1977. The map of the natural vegetation of California. In Barbour, M. G., and Major, J., eds. Terrestrial vegetation of California. New York, Wiley.

Matmon, A.; Schwartz, D. P.; Finkel, R.; Clemmens, S.; and Hanks, T. 2005. Dating offset fans along the Mo- jave section of the San Andreas fault using cosmogenic ${ }^{26} \mathrm{Al}$ and ${ }^{10} \mathrm{Be}$. Geol. Soc. Am. Bull. 117:795-807.

Matti, J. C.; Morton, D. M.; and Cox, B. F. 1992. The San Andreas fault system in the vicinity of the central Transverse Ranges province, southern California. USGS Open-File Rep. 92-354, 40 p., scale 1:250,000.

Minnich, R. A. 1983. Fire mosaics in southern California and northern Baja California. Science 219:1287-1294.

. 1987. Fire behavior in southern California chaparral before fire control: the Mount Wilson burns at the turn of the century. Ann. Assoc. Am. Geogr. 77:599-618. 2007. Climate, paleoclimate and paleovegetation. In Barbour, M. G.; Keeler-Wolf, T.; and Schoenherr, A. A., eds. Terrestrial vegetation of California. 3rd ed. New York, Wiley.

Minnich, R. A., and Chou, Y. H. 1997. Wildland fire patch dynamics in the chaparral of southern California and northern Baja California. Int. I. Wildland Fire $7: 221-248$.

Mooney, H. A., and Parsons, D. J. 1973. Structure and function of the California chaparral-an example from San Dimas. Ecol. Stud. 7:83-112.

Moritz, M. A.; Moody, T. J.; Krawchuk, M. A.; Hughes, M.; and Hall, A. 2010. Spatial variation in extreme winds predicts large wildfire locations in chaparral ecosystems. Geophys. Res. Lett. 37:L04801.

Portenga, E. W., and Bierman, P. R. 2011. Understanding Earth's eroding surface with ${ }^{10} \mathrm{Be}$. GSA Todav 21:4-10.

Riggan, P. J.; Wolden, L. G.; Tissell, R. G.; and Coen, J. 2010. Remote sensing fires and fuel in southern California. In Wade, D., ed. Proceedings of the 3rd Fire Behavior and Fuels Conference, October 25-29, 2010, Spokane, Washington (CD-ROM). Birmingham, AL, International Association of Wildland Fire.

Winkler, E. M. 1973. Stone: properties, durability in man's environment. Berlin, Springer.

Zimmerman, S. G.; Evenson, E. B.; Gosse, J. C.; and Erskine, C. P. 1994. Extensive boulder erosion resulting from a range fire on the type-Pinedale moraines, Fremont Lake, Wyoming. Quat. Res. 42:255-265. 